\title{
Evaluation of a new plant-based formulation for the treat- ment of varroosis in the honey bee colonies: efficacy and safety
}

\author{
Babak RASHID ${ }^{1}$, Abbas KhanI ${ }^{1}$, Vahid GHASEMI ${ }^{2}$, Mohammad GHAdAMYARI ${ }^{3}$, \\ Najmeh SAHEBZADEH ${ }^{1}$, Saeid MoHARRAMIPOUR ${ }^{4}$ \\ ${ }^{1}$ Department of Plant Protection, Faculty of Agriculture, University of Zabol, Zabol, Iran \\ ${ }^{2}$ Department of Plant Production, Faculty of Agriculture, Higher Education Complex of Shirvan, Shirvan, Iran \\ ${ }^{3}$ Department of Plant Protection, Faculty of Agricultural Sciences, University of Guilan, Rasht, Iran \\ ${ }^{4}$ Department of Entomology, Faculty of Agriculture, Tarbiat Modares University, Tehran, Iran
}

Received 27 October 2019 - Revised 18 May 2020 - Accepted 30 June 2020

\begin{abstract}
Research and development of new natural and safe veterinary medicaments to treat honey bee varroosis caused by Varroa destructor Anderson and Trueman is an important step on the path to embarking on organic beekeeping. In the present research, field experiments were conducted to evaluate the efficacy of a new plant-based formulation against varroa mite and its safety for the honey bees during the summer and autumn of 2018 in Shirvan, North Khorasan, Iran. It was found that the corrected efficacy of this formulation in the summer (48.70\%) was significantly higher than that in the autumn (29.08\%). These results proved the importance of ambient temperature on the varroacidal effectiveness of the formulation. An acceptable safety margin for eggs, larvae, adult workers, and queen bees was observed after employing the formulation over a 4-week treatment period in the summer experiment. The effects of the formulation on the enzyme activities and the amounts of energy reserves of the treated bees are also discussed.
\end{abstract}

varroacidal efficacy / ambient temperature / safety margin / energy reserves / enzyme activities

\section{INTRODUCTION}

Beekeepers throughout the world face ongoing challenges due to varroosis, a devastating parasitic disease of the European honey bee Apis mellifera L., caused by Varroa destructor (Anderson and Trueman 2000). In 2017, a number of local professional beekeepers in North Khorasan, Iran were asked to fill out a questionnaire on the strategies employed for protecting their colonies against varroa mite. The results revealed that many of

Corresponding author: V. Ghasemi, ghasemi@cheshirvan.ac.ir

Manuscript editor: Monique Gauthier them rely on formic acid (FA) and oxalic acid (OA) for the treatment of varroosis in honey bee colonies. Despite the acceptable efficacy and relatively satisfactory results, the need for research and development of new, safer alternatives to these organic acids is stressed.

To date, extensive effort has been put in globally to discover a possible application of plant derivatives including essential oils and extracts for varroosis treatment (Imdorf et al. 1999a, b; Schenk et al. 2001; Ariana et al. 2002; Imdorf et al. 2006; Gashout and Guzmán-Novoa 2009; Maggi et al. 2011; DeGrandi-Hoffman et al. 2012; Islam et al. 2016; Ramzia et al. 2017) which has resulted, in some cases, in introducing some effective products to the global market. For 
example, Apilife VAR®, a commercial product composed of a vermiculite tablet impregnated with a mixture of thymol (76\%), eucalyptol (16.4\%), menthol (3.8\%), and camphor (3.8\%), provides suppression of varroa mites in honey bee colonies (Imdorf et al. 1995). A similar product called Thymovar®, based exclusively on thymol, was introduced by Bollhalder (1998) with a very high efficacy rate in the various apiaries. In another study, Tananaki et al. (2014) compared the varroacidal efficacy of Exomite Pro $^{\mathrm{TM}}$ (a thymolbased powder) with Apiguard $\AA$ (a thymol-based gel) in varroa-infected colonies. Recently, HopGuard®, containing natural plant compounds (hop acids) as active ingredients (Rademacher et al. 2015), and Argus Ras, a mixture of extracts of Sophora flavescens, Ginkgo biloba, Gleditsia chinensis, and Teucrium chamaedrys (Stanimirović et al. 2017), were reported as the newest veterinary medicinal products for controlling varroa mite in apiaries.

In 2010, an Iranian research team launched a comprehensive project on the possibility of using essential oils from Iran's medicinal plant flora to control varroa mite. Many species belonging to different plant families were screened in terms of oil yield percentage, varroacidal efficacy as well as safety for the honey bee. The test results showed that some oils such as Thymus kotschyanus Bioss \& Hohen. (containing $47.99 \%$ carvacrol and $30.61 \%$ thymol), Mentha longifolia L. (containing $36.86 \%$ piperitenone, $27.53 \%$ piperitenone oxide, $22.21 \%$ cis piperitone epoxide, and $8.38 \%$ pulegone), Eucalyptus camaldulensis Dehnh. (containing 74.7\% 1,8 -cineol and $8.35 \% \alpha$-pinene) have potential acaricidal efficacy against varroa mite with less toxic effects on honey bee under laboratory conditions (Ghasemi et al. 2011, 2016). In continuation of the project and to achieve a field-suitable compound, the screened oils were formulated by Daya Nanotechnologists Company.

So, in the current research, we intended to evaluate the varroacidal efficacy of this plantbased formulation (hereinafter $\mathrm{PbF}$ ) in varroainfected honey bee colonies taking the season of the year into consideration. The side effects of the $\mathrm{PbF}$ on bee population growth and colony production as well as the enzyme activities and the amounts of energy reserves were also assessed.

\section{MATERIALS AND METHODS}

\subsection{Treatments}

The test $\mathrm{PbF}$ namely Tinavar was manufactured as a water-soluble emulsion by Daya Nanotechnologists Company in Iran. FA (99\%, Merck, Germany) was purchased from Zistazma Company, Ferdowsi University of Mashhad, Iran.

\subsection{Identification of active ingredients of the $\mathrm{PbF}$}

GC analysis was conducted on an Agilent Technology model 7890A gas chromatograph equipped with an FID and a BP-5 (non-polar) capillary column $(30 \mathrm{~m} \times 0.25 \mathrm{~mm} \times 0.25 \mu \mathrm{m}$ film thickness). The oven temperature was maintained at $60{ }^{\circ} \mathrm{C}$ for $4 \mathrm{~min}$ and programmed to increase at $3{ }^{\circ} \mathrm{C} / \mathrm{min}$ to $100{ }^{\circ} \mathrm{C}$ for $2 \mathrm{~min}$ and then $4{ }^{\circ} \mathrm{C} / \mathrm{min}$ to $250{ }^{\circ} \mathrm{C}$ for $5 \mathrm{~min}$. Other operating conditions were as follows: carrier gas $\mathrm{He}$, at a flow rate of $1 \mathrm{~mL} / \mathrm{min}$; injector temperature $260{ }^{\circ} \mathrm{C}$; detector temperature $245{ }^{\circ} \mathrm{C}$; and split 50.1 , column flow ratio, $1: 8 \mathrm{~mL} / \mathrm{min}$. GC/MS analysis was conducted on an Agilent Technology model 7890A coupled with a mass spectroscopy model EI 5975C. The operating conditions of the mass system were identical to those described previously. The mass spectra were obtained at $70 \mathrm{eV}$. The mass range was from $\mathrm{m} / \mathrm{z} 50$ $500 \mathrm{amu}$. Quantitative data were obtained from the electronic integration of the FID peak areas. The active ingredients of the $\mathrm{PbF}$ were identified via comparison of their mass spectra and retention indices with those published in the literature (Adams 1995), and presented in the MS computer library.

\subsection{Season and location of study}

The summer field experiment was performed from 29 June to 9 August 2018 in a private apiary located in Alashlou, a village near Shirvan, North 
Khorasan, Iran (geographical coordinates $-37^{\circ} 33^{\prime} 10^{\prime \prime} \mathrm{N}, 58^{\circ} 14^{\prime} 04^{\prime \prime} \mathrm{E}$; altitude $-1882 \mathrm{~m}$ a.s.l.). The average ambient temperature and the mean percentages of relative humidity recorded during this period were $24.52{ }^{\circ} \mathrm{C}$ (minimum $19.65{ }^{\circ} \mathrm{C}$ and maximum $28.10{ }^{\circ} \mathrm{C}$ ) and $33.38 \%$ (minimum $22 \%$ and maximum $52.50 \%$ ), respectively. The autumn field experiment was carried out from 2 October to 12 November 2018 in the research apiary of Higher Education Complex of Shirvan, North Khorasan, Iran (geographical coordinates-37 $26^{\prime} 04^{\prime \prime} \mathrm{N}$, $57^{\circ} 45^{\prime} 14^{\prime \prime} \mathrm{E}$; altitude $-1067 \mathrm{~m}$ a.s.1.). The average ambient temperature and the mean percentages of relative humidity recorded during this period were $11.63{ }^{\circ} \mathrm{C}$ (minimum $5.35{ }^{\circ} \mathrm{C}$ and maximum $18.55{ }^{\circ} \mathrm{C}$ ) and $54.91 \%$ (minimum $35.50 \%$ and maximum $83.50 \%$ ), respectively.

\subsection{Setting up the colonies}

In the present study, the colonies of Iranian honey bees (Apis mellefera meda Skorikov) housed in Langstroth hives, manually equipped with mesh floors and mobile bottom sticky boards, were used. Each colony consisted of seven combs of worker bees naturally infected by $V$. destructor and a 1-year-old queen. None of the colonies had received any acaricide at least 9 months before the start of the experiments. Prior to applying the treatments, the colonies were equalized in terms of brood and adult worker bee population (Delaplane et al. 2013). The initial varroa infection rate of the colonies was determined via adult and brood honey bee examination (De Jong et al. 1982; Dietemann et al. 2013; Zemene et al. 2015). To estimate the infestation rate of the adult bees, three samples of approximately 100 bees each were separately collected from each colony by brushing them from brood combs into a glass jar containing $150 \mathrm{~mL}$ soapy water. The jar was shaken for $20 \mathrm{~s}$. After $1 \mathrm{~min}$, most of the bees remained floating on the surface of the solution and the mites had dislodged from the bees' body and fallen to the bottom of the jar. The bees were taken out of the jar with the aid of a pair of forceps and examined individually for remaining mites. The number of bees and mites was counted and the proportion of infested individuals was calculated from dividing the number of mites by the number of bees in the sample. To measure the infestation rate of the brood, approximately 100 worker pupae from different brood combs of the colony were removed from their cells and checked for the presence of varroa mites. The number of mites observed was divided by the number of cells opened to obtain the brood mite infestation rate in mites per 100 cells. Eventually, the infection rate of the whole colony was estimated from the mean of the infection percentage of the adult and brood bee samples. The average initial infection rate of the colonies in the summer experiment was $4.94 \%$ with a range from 2 to $10 \%$, and in the autumn experiment, the average was $6.87 \%$ with a range from 4.28 to $14.51 \%$. Moreover, the mean daily natural mite fall per colony over a 3-day pre-treatment period before the beginning of the summer and autumn experiments were $10.81 \pm 0.50$ mites (no significant difference between the test groups; $F=$ 0.952, $\left.d f_{t, e}=4,15, P<0.462\right)$ and $19.48 \pm 1.28$ mites (no significant difference between the test groups; $F=0.406, d f_{t, e}=4,15, P<0.801$ ), respectively.

\subsection{Assessment of varroacidal efficacy}

Based on the average initial infection rate, the colonies were randomly arranged in four treatment groups and one control group as follows:

Group PbF60 $(n=4)$ : treatment consisted of $15 \mathrm{~mL} 10 \%$ solution applied four times at 1-week intervals so that a total of $60 \mathrm{~mL}$ was applied over 4 weeks,

Group PbF80 $(n=4)$ : treatment consisted of $20 \mathrm{~mL} \mathrm{10 \%} \mathrm{solution} \mathrm{applied} \mathrm{four} \mathrm{times} \mathrm{at} \mathrm{1-week}$ intervals so that a total of $80 \mathrm{~mL}$ was applied over 4 weeks,

Group PbF100 $(n=4)$ : treatment consisted of $25 \mathrm{~mL} \mathrm{10 \%} \mathrm{solution} \mathrm{applied} \mathrm{four} \mathrm{times} \mathrm{at} \mathrm{1-week}$ intervals so that a total of $100 \mathrm{~mL}$ was applied over 4 weeks,

Group FA80 $(n=4)$ : treatment consisted of $20 \mathrm{~mL} \mathrm{65 \%} \mathrm{solution} \mathrm{applied} \mathrm{four} \mathrm{times} \mathrm{at} \mathrm{1-}$ week intervals so that a total of $80 \mathrm{~mL}$ was applied over 4 weeks,

Group control $(n=4)$ : treatment consisted of $25 \mathrm{~mL}$ tap water applied four times at 1-week 
intervals so that a total of $100 \mathrm{~mL}$ was applied over 4 weeks.

The values and concentration of the $\mathrm{PbF}$ were determined based on our preliminary field experiments in different apiaries of Shirvan during 2016 and 2017. PbF and FA were diluted in tap water to obtain a desirable concentration. The experiments were conducted using a completely randomized design with four replications for each treatment and control group. To treat the colonies, a piece of an absorbent pad $(5 \times 5 \times 0.5 \mathrm{~cm})$ was placed on top of the brood combs in the center of the hive and the aforementioned values of the treatments were then poured on to it using a syringe. The pad was replaced weekly with a fresh impregnated pad and total treatment period was 4 weeks. Dead mites and debris fell between the frames, through the mesh floor, and on to the board below. To assess the efficacy of the treatments, the boards were removed from the bottom of the hives twice a week and the number of mites fallen on them were counted. After each count, all mites and debris were cleaned from the boards. Then after, the boards were coated with fresh grease and reinstalled in the bottom of the hives. For easy counting, the boards were divided into squares (Dietemann et al. 2013). After 4 weeks of experiments, the colonies were post-treated for a further 2 weeks with $\mathrm{OA}+$ Apistan ${ }^{\circledR}$ and the number of remaining mites in each colony was estimated as described previously. The percentage efficacy of the treatments was determined as follows:

\%efficacy

$=\frac{\text { No.of fallen mites during treatment }}{\text { No.of fallen mites during treatment }+ \text { OA and Apistan }{ }^{\tilde{A}}}$
$\quad \times 100$

Due to considerable natural mite fall in the control colonies, the efficacy of the treatments were corrected using Abbott's formula (Abbott 1925):

$\%$ Corrected efficacy $=\frac{E \mathrm{o}-E \mathrm{c}}{100-E \mathrm{c}} \times 100$ where $E_{\mathrm{o}}=$ observed efficacy $(\%)$ and $E_{\mathrm{c}}=$ control mortality (\%).

\subsection{Assessment of safety for the honey bees}

The effects of the treatments on population growth rate, colony production, and biochemical features of the bees were concurrently evaluated with varroacidal efficacy experiments during the summer.

\subsubsection{Effects on brood and adult bee population}

Changes in population growth rate of the treated and control groups were estimated by recording the brood (eggs, larvae, and pupae) and adult bee population at the beginning and the end of the 4-week treatment period (Delaplane et al. 2013).

\subsubsection{Mortality effects on eggs, larvae, adult workers, and queen bees}

To carry out the procedure, 100 cells of the colonies in brood area containing eggs or 1- to 2-day-old larvae were marked by colored pins before the administration of the treatments. After 7 days, the cells were checked. The sealed cells or those with larvae at last larval instar were considered alive, while in case of the empty cells or ones replaced with a new egg, the brood was considered dead (Giusti et al. 2017). Also, the number of dead bees found in pollen traps or inside the hives as well as the presence of an egg-laying queen in each colony were checked weekly over the entire treatment period.

\subsubsection{Effects on colony production}

Changes in honey production of the treated and control groups were estimated by recording the number of cells containing honey or nectar at the beginning and the end of the treatment period. Moreover, to evaluate the impact of the treatments on pollen collection capacity of forager bees, a plastic trap was installed at the front of the entrance of the hives during the last 2 weeks of the treatment period and the amount of pollen 
collected in the treated groups was weighed and compared with that of the control.

\subsubsection{Effects on biochemical features}

One day before starting the summer experiment, the sealed brood combs were taken from the test colonies and put in a cage with mesh walls. The cage was kept in an incubator set at $32 \pm 2{ }^{\circ} \mathrm{C}, 65 \pm 5 \%$ R.H. in darkness for $24 \mathrm{~h}$. Then, newly emerged worker bees were marked on the dorsal surface of the thorax with a queen marker. On the first day of the treatment period, marked bees were returned to the test colonies and remained for 4 weeks. Subsequently, 20 treated bees were collected from each treatment and control group and maintained at $-20{ }^{\circ} \mathrm{C}$ until required. The frozen bees were homogenized in $200 \mu \mathrm{l}$ phosphate buffer $\mathrm{pH} 7.0$ containing Triton $\mathrm{X}-100$. The homogenates were centrifuged $\left(12,000 \times g\right.$ for $10 \mathrm{~min}$ at $\left.4{ }^{\circ} \mathrm{C}\right)$ and the supernatants were used for the biochemical tests.

The specific activity of AChE was determined according to the method of Ellman et al. (1961) using acetylthiocholine iodide as substrate. Increase in absorbance was recorded at $415 \mathrm{~nm}$ using a microplate reader (Awareness Technology Stat Fax 3200®). Glutathione $S$-transferase (GST) specific activity was determined based on the method of Habig et al. (1974) slightly modified by Mahdavi Moghadam et al. (2012). Increase in absorbance was recorded at $360 \mathrm{~nm}$ using the same microplate reader. For general esterases (EST) assay, alpha-naphthyl acetate $(\alpha-$ $\mathrm{NA}$ ) and beta-naphthyl acetate ( $\beta$-NA) were used as substrate and the naphthol production was monitored by measuring absorbance at 450 and $540 \mathrm{~nm}$, respectively, for $\alpha$-NA and $\beta$-NA using the same microplate reader as a kinetic mode (Van Asperen 1962).

The amounts of carbohydrate, glycogen, and lipid were measured by the method of Yuval et al. (1998). Total protein was determined according to Bradford (1976) method with BSA as standard.

\subsection{Meteorological data}

In both experiments, maximum, minimum, and average temperature and relative humidity were obtained from the nearest weather station to the locations of study.

\subsection{Statistics}

Data were analyzed using SPSS 24.0 software for ANOVA and means separated with Tukey's test $(P<0.05)$. All data were expressed as mean \pm SEM. In case of necessity, statistical comparison between two treatments was performed using Student's $t$ test. The data were tested for normality using Kolmogorov-Smirnov test and if needed, they were transformed to meet statistical assumptions. The charts were prepared in Microsoft Excel 2013.

\section{RESULTS}

\subsection{Active ingredients of the $\mathrm{PbF}$}

The results of the chemical analysis of the $\mathrm{PbF}$ are provided in Table I. 1,8-Cineole (22.25\%), camphor $(15.70 \%)$, carvacrol $(11.97 \%), \beta-$ thujone $(10.76 \%)$, thymol $(7.76 \%), \alpha$-thujone $(7.53 \%)$, and cymene $(4.87 \%)$ were the major active ingredients.

\subsection{Varroacidal efficacy}

The efficacy of the treatments against varroa mite during the summer experiment is presented in Table II. All treatments indicated significantly higher levels of efficacy than the control $(F=$ 46.87, $\left.d f_{t, e}=4,15, P<0.001\right)$. The percentage of efficacy significantly increased as value of the $\mathrm{PbF}$ was increased from 60 to $100 \mathrm{ml}$. However, the differences between the efficacy of $\mathrm{PbF} 80$ (53.17\%) and PbF100 (59.32\%) were not statistically significant. Lack of any significant difference between the efficacy of PbF100 (59.32\%) and FA80 (66.27\%) was noticed. We also observed $20.73 \%$ mite mortality in the control group which shows that natural mite fall occurred during the treatment period. After applying Abbott's formula, the efficacy of PbF60, PbF80, PbF100, and FA80 were corrected to $26.90,40.93,48.70$, and $57.45 \%$, respectively.

Table III shows the varroacidal efficacy of the treatments during the autumn experiment. Similar 
Table I.. Active ingredients of the plant-based formulation (Tinavar)

\begin{tabular}{|c|c|c|}
\hline Compounds & Retention index & Composition (\%) \\
\hline Tricyclene & 5957 & 0.13 \\
\hline$\alpha$-Pinene & 6332 & 1.57 \\
\hline Camphene & 683 & 2.27 \\
\hline Verbenene & 7026 & 0.22 \\
\hline Sabinene & 7724 & 0.70 \\
\hline$\beta$-Pinene & 7832 & 0.35 \\
\hline$\beta$-Myrcene & 8412 & 0.54 \\
\hline Phellandrene & 891 & 0.17 \\
\hline$\alpha$-Terpinene & 9403 & 0.64 \\
\hline Cymene & 9742 & 4.87 \\
\hline 1,8-Cineole & 9989 & 22.25 \\
\hline$\gamma$-Terpinene & 11,195 & 1.39 \\
\hline$\alpha$-Terpinolene & 12,495 & 0.16 \\
\hline Linalool & 1308 & 1.27 \\
\hline$\beta$-Thujone & 13,244 & 10.76 \\
\hline$\alpha$-Thujone & 13,732 & 7.53 \\
\hline Chrysanthenone & 14,112 & 0.25 \\
\hline Trans-pinocarveol & 14,718 & 0.89 \\
\hline Camphor & 14,939 & 15.70 \\
\hline$\rho$-Mentha-1,5-dien-8-ol & 15,201 & 0.17 \\
\hline Trans - $\rho$-menth-2-en-1,8-diol & 16,069 & 0.26 \\
\hline 3-Cyclohexen-1-ol, 4-methyl-1-(1-methylethyl)- & 16,495 & 0.62 \\
\hline$\beta$-Fenchyl alcohol & 17,142 & 0.21 \\
\hline Myrtenol & 17,384 & 0.50 \\
\hline Verbenone & 17,943 & 0.17 \\
\hline 2-Isopropyl-5-methyl-1-methoxybenzene & 19,361 & 0.28 \\
\hline Carvacrol methyl ether & 19,848 & 0.84 \\
\hline Bicyclo[3.1.1]hept-2-en-4-ol, 2,6,6-trimethyl-, acetate & 20,716 & 1.08 \\
\hline Bornyl acetate & 21,897 & 0.27 \\
\hline Thymol & 22,524 & 7.76 \\
\hline Carvacrol & 22,935 & 11.97 \\
\hline Carvacryl acetate & 25,764 & 0.32 \\
\hline Trans -caryophyllene & 27,433 & 0.56 \\
\hline Total identified & & 96.68 \\
\hline
\end{tabular}

Bold values indicate the major components of the plant-based formulation

to the previous experiment, there were statistically significant differences between the efficacy of the test treatments and control $\left(F=303.79, d f_{t, e}=\right.$ $4,15, P<0.001)$. Our results indicated that the varroacidal efficacy significantly increased as value of the $\mathrm{PbF}$ was increased. However, the difference between the efficacy of $\mathrm{PbF} 80$ (43.35\%) and PbF100 (41.27\%) was not significant. Unlike the summer experiment results, a statistically significant difference was found between the efficacy of PbF100 (41.27\%) and FA80 (59.74\%). Regarding $17.20 \%$ natural mite fall in 
Table II.. Varroacidal efficacy of the treatments during the summer experiment

\begin{tabular}{llllll}
\hline Treatments & \multicolumn{3}{c}{ Number of fallen mites } & \multirow{2}{*}{ Efficacy (\%) } & Corrected efficacy (\%) \\
\cline { 2 - 4 } & Treatment period & Post-treatment period & \multicolumn{2}{c}{ Total } & \\
\hline PbF60 & $683.25 \pm 227.25$ & $903.25 \pm 221.45$ & $1586.5 \pm 442.75$ & $42.03 \pm 3.17^{\mathrm{c}}$ & $26.90 \pm 3.99^{\mathrm{c}}$ \\
PbF80 & $471.50 \pm 57.92$ & $425.25 \pm 71.27$ & $896.75 \pm 126.91$ & $53.17 \pm 2.15^{\mathrm{bc}}$ & $40.93 \pm 2.71^{\mathrm{b}}$ \\
PbF100 & $510.25 \pm 55.18$ & $344.00 \pm 15.20$ & $854.25 \pm 65.23$ & $59.32 \pm 2.19^{\mathrm{ab}}$ & $48.70 \pm 2.76^{\mathrm{ab}}$ \\
FA80 & $316.00 \pm 18.37$ & $161.25 \pm 12.97$ & $477.25 \pm 28.65$ & $66.27 \pm 1.28^{\mathrm{a}}$ & $57.45 \pm 1.61^{\mathrm{a}}$ \\
Control & $120.25 \pm 14.40$ & $504.25 \pm 112.3$ & $624.50 \pm 109.10$ & $20.73 \pm 3.57^{\mathrm{d}}$ & \\
\hline
\end{tabular}

Means marked with the same letter in each column are not statistically different (Tukey's test, $P<0.05$ )

the control group, the efficacy of PbF60, PbF80, $\mathrm{PbF} 100$, and FA80 were corrected to 24.38 , $31.58,29.08$, and $51.38 \%$, respectively.

Moreover, Fig. 1 shows the comparative efficacy of the test treatments during the summer and autumn experiments. Findings indicate that $\mathrm{PbF} 80, \mathrm{PbF} 100$, and FA80 have significantly higher varroacidal efficacy in the summer than in the autumn.

\subsection{Safety for the honey bee}

\subsubsection{Changes in brood and adult bee population}

The mean population of brood and adult bees in all test groups at the beginning of the summer experiment were $21,396.15 \pm 80.20$ brood (no significant difference between the groups; $F=1.72$, $\left.d f_{t, e}=4,15, P=0.197\right)$ and $8294.5 \pm 28.14$ bees (no significant difference between the groups; $\left.F=1.47, d f_{t, e}=4,15, P=0.260\right)$, respectively.
Results presented in Table IV indicate that brood area in both treated and control groups declined by over $50 \%$, showing a great reduction in the number of eggs laid by the queens. The lowest decline was attributed to the group treated with PbF60 ( $-56.4 \%)$, and no significant difference was found among the rest of the groups $(F=$ 2.91, $\left.d f_{t, e}=4,15, P=0.058\right)$. In contrast, the overall increase in adult bee population of the treated groups was significantly higher than that of the control $\left(F=19.51, d f_{t, e}=4,15, P<0.001\right)$ (Table IV). The highest increase was related to the colonies treated with PbF60 (+ 98.71\%), FA80 (+ $80.98 \%)$, and $\mathrm{PbF} 80$ (+73.05\%).

\subsubsection{Mortality effects on eggs, larvae, adult workers, and queen bees}

Despite significant differences between some of the treatments $\left(F=4.87, d f_{t, e}=4,15, P=\right.$ 0.01 ), none showed any significant toxic effects on eggs and larvae of the honey bees when

Table III.. Varroacidal efficacy of the treatments during the autumn experiment

\begin{tabular}{llllll}
\hline Treatments & \multicolumn{3}{c}{ Number of fallen mites } & \multirow{2}{*}{ Efficacy (\%) } & Corrected efficacy (\%) \\
\cline { 2 - 4 } & Treatment period & Post-treatment period & \multicolumn{2}{c}{ Total } & \\
\hline PbF60 & $178.25 \pm 47.26$ & $296.25 \pm 76.88$ & $474.50 \pm 124.1$ & $37.38 \pm 0.5^{\mathrm{c}}$ & $24.38 \pm 0.60^{\mathrm{c}}$ \\
PbF80 & $251.50 \pm 108.49$ & $318.25 \pm 125.86$ & $569.75 \pm 234.08$ & $43.35 \pm 0.94^{\mathrm{b}}$ & $31.58 \pm 1.13^{\mathrm{b}}$ \\
PbF100 & $277.25 \pm 158.59$ & $375.25 \pm 200.63$ & $652.50 \pm 359.19$ & $41.27 \pm 0.86^{\mathrm{b}}$ & $29.08 \pm 1.03^{\mathrm{b}}$ \\
FA80 & $366.25 \pm 61.19$ & $243.50 \pm 32.23$ & $609.75 \pm 92.62$ & $59.74 \pm 1.18^{\mathrm{a}}$ & $51.38 \pm 1.42^{\mathrm{a}}$ \\
Control & $102.00 \pm 26.00$ & $505.50 \pm 151.93$ & $607.50 \pm 177.6$ & $17.20 \pm 0.74^{\mathrm{d}}$ & \\
\hline
\end{tabular}




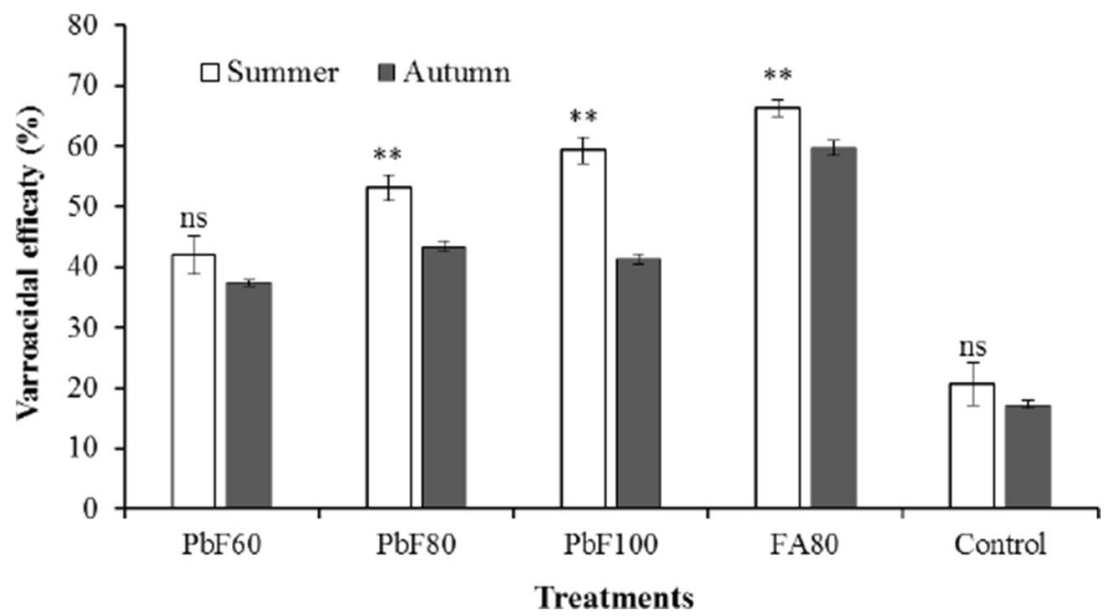

Figure 1. Comparative varroacidal efficacy of the treatments during the summer and autumn experiments. Bars were compared pairwise by Student's $t$ test. Statistically significant differences are denoted with * $(P<0.05), * *(P$ $<0.01$ ), and ns (non-significant).

compared with the control. The number of dead worker bees in pollen traps or on the floor of the hives was negligible. Furthermore, all the queen bees showed normal activity during and after the treatment period and no winter colony loss was observed (Table V).

\subsubsection{Effects on colony production}

The effects of the test treatments on honey and pollen yield of the colonies are given in Table VI. An increase in the amount of honey production in the treated groups was not significantly different from that of the control
$\left(F=0.36, d f_{t, e}=4,15, P=0.827\right)$. Interestingly, the amount of collected pollen in all treated groups except PbF100 was significantly higher than that in the control $(F=$ 6.76, $\left.d f_{t, e}=4,15, P=0.003\right)$.

\subsubsection{Effects on the enzyme activities}

The effect of the treatments on the specific activity of AChE is shown in Fig. 2a. The highest activity was attributed to the bees treated with PbF60 $(0.41 \mu \mathrm{mol} / \mathrm{min} / \mathrm{mg}$ protein $)(F=12.56$, $\left.d f_{t, e}=4,15, P=0.001\right)$ and no significant differences were found between the rest of the treatment

Table IV.. Changes in brood and adult bee population during the summer application of the treatments

\begin{tabular}{|c|c|c|c|c|c|c|}
\hline \multirow[t]{2}{*}{ Treatments } & \multicolumn{3}{|c|}{ Number of brood bees } & \multicolumn{3}{|c|}{ Number of adult worker bees } \\
\hline & Initial & Final & Changes $(\%)$ & Initial & Final & Changes $(\%)$ \\
\hline PbF60 & $21,688 \pm 20.25$ & $9457 \pm 511.62^{* *}$ & $-56.40 \pm 2.35^{\mathrm{a}}$ & $8376 \pm 88.72$ & $16,652 \pm 751.18^{* *}$ & $98.71 \pm 8.06^{\mathrm{a}}$ \\
\hline $\mathrm{PbF} 80$ & $21,404 \pm 196.68$ & $8363 \pm 775.08^{* * *}$ & $-60.92 \pm 3.62^{\mathrm{ab}}$ & $8238 \pm 65.27$ & $14,248 \pm 507.52^{* *}$ & $73.05 \pm 6.86^{\mathrm{ab}}$ \\
\hline $\mathrm{PbF} 100$ & $21,343 \pm 210.44$ & $7735 \pm 285.42^{* *}$ & $-63.77 \pm 1.19^{\mathrm{ab}}$ & $8262 \pm 26.61$ & $12,328 \pm 510.51^{* *}$ & $49.20 \pm 6.07^{\mathrm{bc}}$ \\
\hline FA80 & $21,465 \pm 104.57$ & $7695 \pm 476.92^{* *}$ & $-64.15 \pm 2.23^{\mathrm{ab}}$ & $8226 \pm 55.05$ & $14,883 \pm 241.54^{* *}$ & $80.98 \pm 3.84^{\mathrm{a}}$ \\
\hline Control & $21,080 \pm 212.71$ & $5832 \pm 1145.99^{* *}$ & $-72.21 \pm 5.69^{\mathrm{b}}$ & $8370 \pm 46.35$ & $10,698 \pm 441.12^{*}$ & $27.89 \pm 5.81^{\mathrm{c}}$ \\
\hline
\end{tabular}

Means were compared pairwise for each parameter between initial and final status by Student's $t$ test. Statistically significant differences are denoted with $\rightarrow(P<0.05)$, ** $(P<0.01)$, and $n s$ (no significant difference). Also, means marked with the same letter in each column are not statistically different (Tukey's test, $P<0.05$ ) 
Table V.. Mortality effects of the treatments on eggs, larvae, adult workers, and queen bees during the summer experiment

\begin{tabular}{llll}
\hline Treatments & Egg and larval mortality $(\%)$ & Number of dead worker bees & Number of lost queen bees \\
\hline PbF60 & $23.75 \pm 2.06^{\mathrm{ab}}$ & $2^{\mathrm{a}}$ & $0^{\mathrm{a}}$ \\
$\mathrm{PbF} 80$ & $23.00 \pm 1.08^{\mathrm{ab}}$ & $0^{\mathrm{a}}$ & $0^{\mathrm{a}}$ \\
$\mathrm{PbF} 100$ & $27.25 \pm 1.60^{\mathrm{a}}$ & $2^{\mathrm{a}}$ & $0^{\mathrm{a}}$ \\
$\mathrm{FA} 80$ & $16.00 \pm 2.74^{\mathrm{b}}$ & $1^{\mathrm{a}}$ & $0^{\mathrm{a}}$ \\
Control & $18.50 \pm 2.22^{\mathrm{ab}}$ & $0^{\mathrm{a}}$ & $0^{\mathrm{a}}$ \\
\hline
\end{tabular}

Means marked with the same letter in each column are not statistically different (Tukey's test, $P<0.05$ )

groups and the control. Different values of the test $\mathrm{PbF}$ significantly reduced GST specific activity in comparison to FA80 $(1.33 \mu \mathrm{mol} / \mathrm{min} / \mathrm{mg}$ protein $)$ and the control $(1.51 \mu \mathrm{mol} / \mathrm{min} / \mathrm{mg}$ protein $)(F=$ 57.17, $d f_{t, e}=4,15, P=0.001$ ) (Fig. 2b). The lowest GST activity was observed in the group treated with PbF100 (0.24 $\mu \mathrm{mol} / \mathrm{min} / \mathrm{mg}$ protein). Also, compared with the control, the groups treated with the test PbF generally showed lower $\alpha$ $\operatorname{EST}\left(F=45.05, d f_{t, e}=4,15, P<0.001\right)$ (Fig. 2c) and $\beta$-EST specific activities $\left(F=6.37, d f_{t, e}=\right.$ 4,15, $P=0.008$ ) (Fig. 2d).

\subsubsection{Effects on the amounts of energy reserves}

The amounts of energy storage macromolecules were significantly reduced in the treated groups when compared with the control (Fig. 3). The carbohydrate amounts in the groups treated with PbF60 (0.11 mg/bee), PbF80 (0.69 mg/bee), PbF100 (0.15 mg/bee), and FA80 (0.18 mg/bee) were significantly lower than that in control $(0.26 \mathrm{mg} /$ bee $)\left(F=31.46, d f_{t, e}=4,15\right.$,
$P<0.001$ ) (Fig. 3a). In the case of glycogen, the lowest amounts were attributed to the groups treated with PbF80 (0.02 mg/bee), PbF60 (0.03 mg/ bee), and FA80 (0.17 mg/bee). However, the amount of this macromolecule in the group treated with PbF100 (0.23 mg/bee) was not significantly different from that in the control $(0.27 \mathrm{mg} / \mathrm{bee})$ $\left(F=12.28, d f_{t, e}=4,15, P=0.001\right)$ (Fig. 3b). Compared with the control, the lipid amounts in all treated groups declined by over $50 \%(F=$ 63.90, $d f_{t, e}=4,15, P<0.001$ ) (Fig. 3c). It was also found that the total amounts of protein in the groups treated with the $\mathrm{PbF}$ were significantly lower than that in FA80-treated and the control groups $\left(F=447.16, d f_{t, e}=4,15, P<0.001\right)$ (Fig. 3d).

\section{DISCUSSION}

The present study focused on the possibility of applying a new essential oil-containing formulation for the control of varroa mite in the honey bee colonies.

The GC and GC/MS results proved that seven monoterpenoids including 1,8-cineole, camphor,

Table VI.. Effects of the treatments on colony production during the summer experiment

\begin{tabular}{lll}
\hline Treatments & Honey production increase $(\%)$ & Collected pollen $(\mathrm{g})$ \\
\hline $\mathrm{PbF} 60$ & $282.48 \pm 86.57^{\mathrm{a}}$ & $164.78 \pm 8.53^{\mathrm{a}}$ \\
$\mathrm{PbF} 80$ & $357.81 \pm 84.43^{\mathrm{a}}$ & $157.05 \pm 8.05^{\mathrm{a}}$ \\
$\mathrm{PbF} 100$ & $290.80 \pm 43.84^{\mathrm{a}}$ & $141.23 \pm 6.97^{\mathrm{ab}}$ \\
$\mathrm{F} 880$ & $277.63 \pm 68.06^{\mathrm{a}}$ & $166.83 \pm 3.98^{\mathrm{a}}$ \\
Control & $227.31 \pm 90.90^{\mathrm{a}}$ & $123.70 \pm 6.43^{\mathrm{b}}$ \\
\hline
\end{tabular}



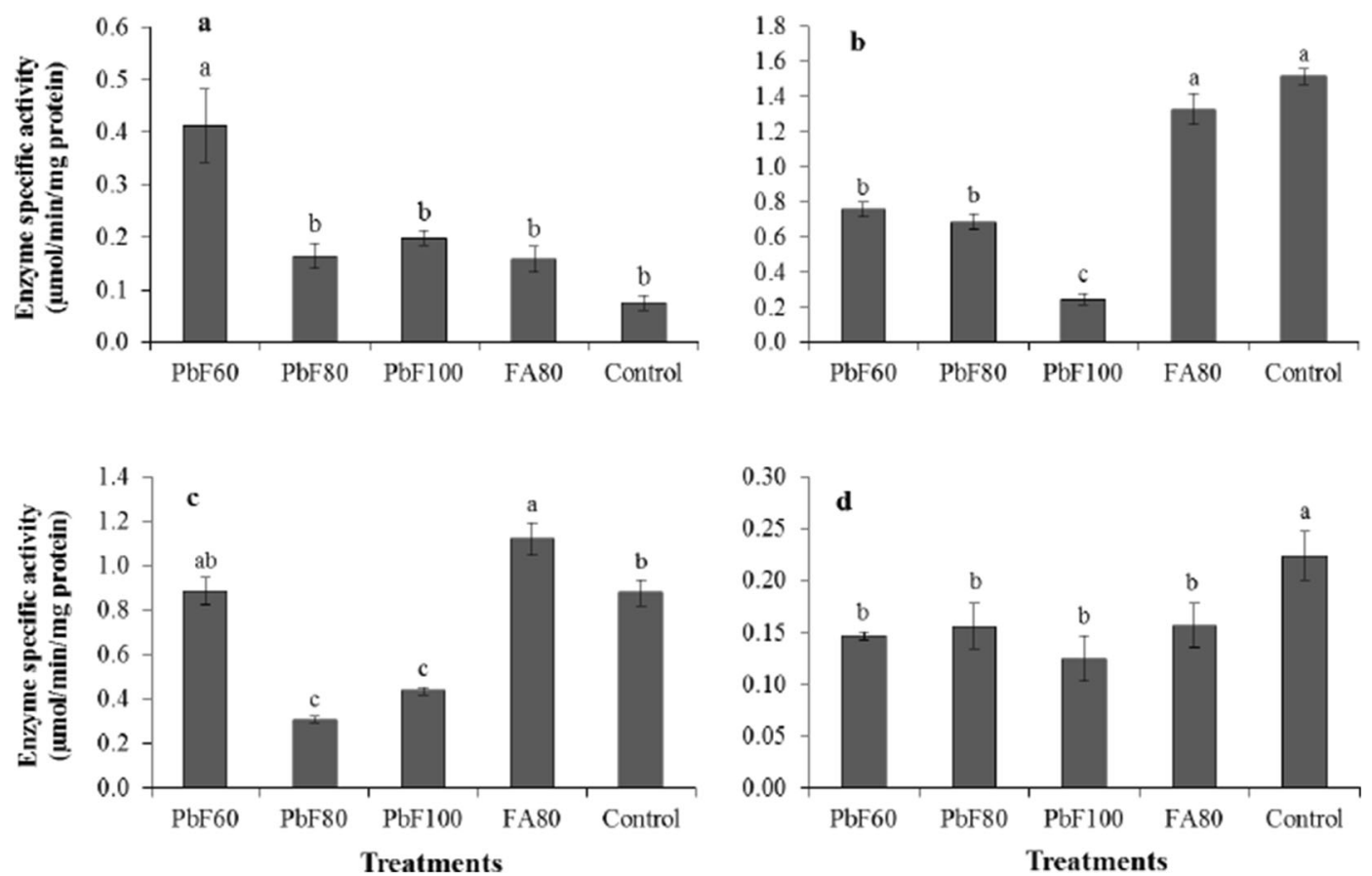

Figure 2. Effects of the treatments on a acetylcholinesterase, $\mathbf{b}$ glutathione S-transferase, $\mathbf{c} \alpha$-esterase, and $\mathbf{d} \beta$ esterase specific activities of the treated bees during the summer experiment. Bars marked with the same letters are not statistically different (Tukey's test, $P<0.05$ ).

carvacrol, $\beta$-thujone, thymol, $\alpha$-thujone, and cymene comprise $80.84 \%$ of the components involved in the test PbF. Imdorf et al. (1999a, b) reviewed the efficacy and safety of these components for the treatment of honey bee varroosis. 1,8-Cineole, the most abundant active ingredient of the $\mathrm{PbF}$, or essential oils rich in this component have already been proven to be effective against varroa mite (Imdorf et al. 2006; Damiani et al. 2009; Maggi et al. 2011; Ghasemi et al. 2016). Camphor, carvacrol, $\beta$-thujone, $\alpha$-thujone, and thymol, whether pure or in a form of commercial product, offered promising varroacidal effects (Calderone and Spivak 1995; Imdorf et al. 1995; Bollhalder 1998; Imdorf et al. 1999a, b; Ruffinengo et al. 2005; Damiani et al. 2009; Tananaki et al. 2014; Gracia et al. 2017). Therefore, the efficacy of our test $\mathrm{PbF}$ could be attributed to the high potential of its major components.

A comparison of our trial results with previous studies is not always possible since in several studies the natural mite mortality was omitted. Nevertheless, the varroacidal efficacy of PbF100 is comparable with that of FA80 $(57.45 \%)$ reported in the present research, Apiguard ${ }^{\circledR}(46 \%)$ (Gregorc and Planinc 2005), Apilife VAR ${ }^{\circledR}$ (53.8\%) (Coffey and Breen 2013), Exomite Pro $^{\text {TM }}(39.4 \%)$, and Apiguard $®(40.09 \%)$ (Tananaki et al. 2014). However, our tested formulation showed a lower varroacidal efficacy in comparison with Apilife VAR® $(81.3 \%)$ and Apiguard ${ }^{\circledR}$ (95.5\%) (Floris et al. 2004), Thymovar® (84.7\%) (Coffey and Breen 2013), HopGuard® (88\%) (Rademacher et al. 2015), Apiguard® (76.1\%) (Giacomelli et al. 2016), Argus Ras (80.89\%) (Stanimirović et al. 2017), and oregano oil (97.4\%) (Sabahi et al. 2017).

Despite many advantages, a major criticism of essential oil-based varroacides is their inconsistent efficacy and great variability between studies, the seasons of the year, and localities (Calderone and Spivak 1995; Imdorf et al. 1999a, b; Rosenkranz et al. 2010). Since most fumigant 

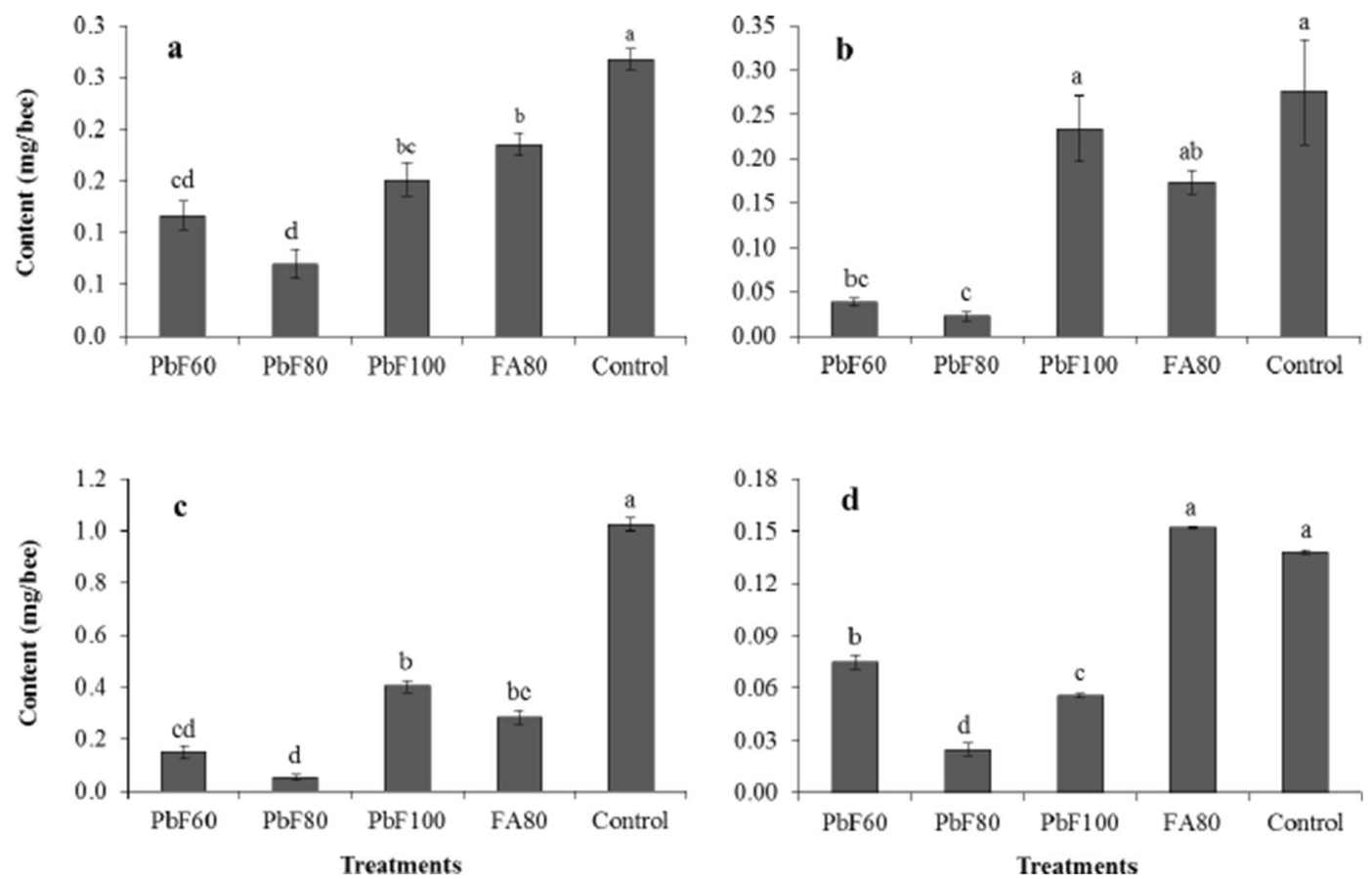

Figure 3. Effects of the treatments on a carbohydrate, $\mathbf{b}$ glycogen, $\mathbf{c}$ lipid, and $\mathbf{d}$ total protein content of the treated bees during the summer experiment. Bars marked with the same letters are not statistically different (Tukey's test, $P$ $<0.05)$.

varroacides act via the evaporation of the active ingredients which is temperature dependent, the season of the year or the ambient and colony temperature during treatment period can significantly influence their effectiveness. For example, the efficacy of Apilife VAR® as an autumn treatment in a cool climate of Ireland was $53.8 \%$ (Coffey and Breen 2013), whereas this product showed $81.3 \%$ efficacy in Italy during the summer (Floris et al. 2004). In a 3-year study in Karaj, Iran, Bahreini et al. (2004) found a significant positive correlation between FA mite mortality and temperature. They stated that the efficacy of this acid during 25 Nov-13 Dec 1998 (mean temperature $11.09{ }^{\circ} \mathrm{C}$ ) and 20 Oct-8 Nov 1999 (mean temperature $13.72{ }^{\circ} \mathrm{C}$ ) was significantly lower than that during 26 Sep-18 Oct 2000 (mean temperature $19.44{ }^{\circ} \mathrm{C}$ ). As it was expected, the efficacy of our test $\mathrm{PbF}$, as a volatile compound, during the summer (mean temperature $24.52{ }^{\circ} \mathrm{C}$ ) was significantly higher than that in the autumn (mean temperature $11.63{ }^{\circ} \mathrm{C}$ ). It is noteworthy that, on some days when there were low temperatures, neither PbF nor FA were sufficiently evaporated even 1 week after their administration to the colonies. Thus, the greater efficacy of the $\mathrm{PbF}$ in the summer experiment could be mainly linked to its higher evaporation rate, thereby releasing more active ingredients within the colony. Despite all these facts, the lower efficacy of FA80 in our experiments compared with the same previous studies remains controversial.

It was assumed that employing the right delivery method would ensure the continuous release of the active ingredients for a relatively prolonged period of time, thereby enhancing the varroacidal efficacy of the treatments. In our preliminary experiments, $60-\mathrm{mL}$ single-use plastic containers with some small holes on the sides and a piece of cotton inside were used for administering the $\mathrm{PbF}$ and $\mathrm{FA}$ to the colonies, as most beekeepers in Iran do. We observed that this administration method has a main drawback in that bees plug the holes using propolis and do not allow the 
vapors to escape from the container, especially during the nectar flow in spring and summer. In order to overcome this problem and provide an easy-to-apply application method which is capable of slow release of the vapors, a piece of an absorbent pad was used for administering the test treatments. Some researchers reported that absorbent pads are a simple and effective means of administering fumigant varroacides such as FA and essential oil-based compounds to the varroa-infected colonies (Amrine and Noel 2006; Amrine et al. 2007; Gashout 2008). In contrast, Sabahi et al. (2017) compared three different miticide delivery systems and showed that using absorbent pads as a vehicle to deliver a $7 \%$ solution of a mixture of oregano and clove oils diluted in ethanol yielded the lowest rate of mite control. However, these authors noted that a quick evaporation of the ethanol from the solution possibly decreased the release rate of the oils, thereby reducing varroacidal efficacy. In the present research, the evaporation slope of the treatments for each week of the treatment period was not calculated. Nevertheless, it seems that the estimation of correlation between daily evaporation rate of the treatments from the pad and daily mite fall could facilitate making some adjustments to our delivery method.

The place for fumigant treatment inside the hive would also affect the distribution pattern of its toxic vapors (Amrine and Noel 2006; Imdorf et al. 1999a, b; Imdorf and Bogdanov 1999). The major reason that we applied the $\mathrm{PbF}$ over the brood combs was due to the higher molar mass $(M)$ and density $(\rho)$ of its major components $(1,8$ cineole, $M=154.24 \mathrm{~g} / \mathrm{mol}, \rho=922 \mathrm{~kg} / \mathrm{m}^{3}$; camphor, $M=152.23 \mathrm{~g} / \mathrm{mol}, \rho=990 \mathrm{~kg} / \mathrm{m}^{3}$; carvacrol, $M=150.21 \mathrm{~g} / \mathrm{mol}, \rho=977 \mathrm{~kg} / \mathrm{m}^{3}$; thujone, $M=152.23 \mathrm{~g} / \mathrm{mol}, \rho=920 \mathrm{~kg} / \mathrm{m}^{3}$; and thymol, $\left.M=150.22 \mathrm{~g} / \mathrm{mol}, \rho=960 \mathrm{~kg} / \mathrm{m}^{3}\right)$ than those of dry air $\left(M=28.97 \mathrm{~g} / \mathrm{mol}, \rho=1.22 \mathrm{~kg} / \mathrm{m}^{3}\right)$. Also, regarding the low boiling point and the high vapor pressure of the monoterpenoids ( $\mathrm{Li}$ and Perdue 1998; Badawy et al. 2016; Dhifi et al. 2016), the warm air rising up from the space between the brood frames activates the $\mathrm{PbF}$ in the absorbent pad leading to emission rate increase. Similarly, Apilife VAR ${ }^{\circledR}$ tablets and Thymovar ${ }^{\circledR}$ wafers are recommended by the manufacturers to be placed on the brood combs because application from the bottom reduces their efficiency considerably (Imdorf et al. 1995; Bollhalder 1998; Coffey and Breen 2013). We speculate that placing the $\mathrm{PbF}$ in the four corners of the hive on top of the frames would lead to a more uniform distribution of the vapors in the hive atmosphere, thereby achieving a higher varroacidal efficacy.

The controversial point of the study is that the $\mathrm{PbF}$ is probably effective only against phoretic mites present on the adult bees body, and its vapors are unlikely to penetrate through wax cappings and kill the mites in reproductive phase because no noticeable mortality was observed in mites inside the sealed brood cells over the treatment periods. Since the absence of brood in colony would result in most of the mites being transferred to adult bees body and more exposed to treatments (Dietemann et al. 2013), the integration of the $\mathrm{PbF}$ with artificial broodless colony conditions achieved by queen caging technique may lead to a greater varroacidal efficacy. In this context, Giacomelli et al. (2016) reported that the concurrent application of Apiguard $\AA$ and queen caging resulted in higher varroacide performance. In a recent study, Gregorc et al. (2017) recommended combining oxalic acid application with caging the queen as an effective management program for varroa mite control.

The effectiveness of any anti-varroa drug is not only restricted to the power of killing the mites, as its safety for the honey bee colonies, beekeepers, and consumers of bee products should also be considered. The current knowledge of the deleterious effects of conventional acaricides on honey bee health was summarized by Tihelka (2018). This author noted that even plant-based substances and organic acids at recommended doses can lead to high bee mortality and interruption of colony growth and performance. For example, applying $40 \mathrm{~g}$ thymol-based powder for 4 weeks caused a great reduction of brood population and high mortality of adult bees (Tananaki et al. 2014). In another study, it was indicated that Varterminator, a new medicine made of a gel containing formic acid, causes a high mortality of the honey bee eggs (Giusti et al. 2017).

In a previous study by our colleagues (Ghasemi et al. 2016), it was observed that the honey bee 
foragers are highly attracted to T. kotschyanus, M. longifolia, and E. camaldulensis flowers as sources of nectar and pollen. They reported that essential oils from these plant species, which the major components of the $\mathrm{PbF}$ are derived from, cause the least toxic effects on the honey bees in laboratory conditions. In confirmation with this report, our test results proved the safety of the $\mathrm{PbF}$ for different developmental stages of the worker bees as well as for the queens' health. These findings agree with those of previous researchers who found menthol (Gashout and Guzmán-Novoa 2009), thymol (Charpentier et al. 2014), HopGuard® (Rademacher et al. 2015), neem (Azadirachta indica) oil (GonzálezGómez et al. 2016), and oregano oil (Sabahi et al. 2017) to be safe compounds for the honey bees.

Being free of disease and proper nutritional status are evidently among the most important factors contributing to colony strength and growth. Hence, it is thought likely that the significant increase of the adult bee population in the treated groups is linked to the noticeable reduction of varroa infection level as well as more pollen provided by the forager bees. Albeit, given the high initial amounts of brood, a more adult bee population was expected at the end of the treatment period. It seems that great reduction in the rate of oviposition of the queens, due in part to the shortage of nectar flow over the last 2 weeks of the treatment period, is the main reason why the colonies did not grow well. In addition, it should not be neglected that the inability of the $\mathrm{PbF}$ to kill the mites within the sealed brood cells would lead to the emergence of varroa-parasitized bees that have a significantly reduced lifespan (Amdam et al. 2004).

Being aware of the changes of enzyme activities and energy reserves amounts after exposure to xenobiotics allows for a better understanding of how varroacides affect the biochemical features of honey bees, and how honey bees detoxify the toxic molecules and rid themselves of the stress conditions.

$\mathrm{AChE}$ is one of the main sites of action for toxic vapors of essential oils and monoterpenoids in different insect species (Kostyukovsky et al. 2002; Shaaya and Rafaeli 2007; Rajendran and Sriranjini 2008). Our enzyme assays revealed that the PbF80 and PbF100 had no significant effect on the bee brain AChE activity. Similar results were obtained in case of coumaphos (Weick and Thorn 2002) as well as amitraz, flumethrin, thymol, and thymol blended with essential oils (Loucif-Ayad et al. 2008). It is possible that the active ingredients of the $\mathrm{PbF}$ interfere with other target sites in the CNS of the honey bees including octopamine and GABA-gated chloride channels. GST and ESTs are the main enzymes responsible for the metabolism and detoxification of xenobiotics (Grant and Matsumura 1989; Li et al. 2007). In a research by Loucif-Ayad et al. (2008), it was found that amitraz and flumethrin significantly increased GST specific activity in the larval instars, pupae, and newly emerged worker bees in comparison with thymol, thymol blended with essential oils, and control. Low doses of acetamiprid, pymetrozine, and pyridalyl caused a significant increase in the GST activity of the honey bee, while this enzyme was significantly inhibited at higher doses (Badawy et al. 2015). Zhu et al. (2017) proved that acephate (Bracket $\left.{ }^{\circledR}\right)$ and the mixture of imidaclopride (Advise $\AA$ ) + Bracket ${ }^{\circledR}$ suppressed esterase activity in the honey bees. Although we expected a significant increase in the specific activities of the detoxifying enzymes, long-term exposure of the bees to the $\mathrm{PbF}$, thereby receiving high doses of its toxic vapors, possibly led to inhibition of GST and ESTs activities.

Carbohydrate, lipid, and protein are the main molecules stored in the fat body that are used as energy sources for life activities in insects (Van der Horst et al. 1997). Some varroacides have been shown to impose metabolic costs of detoxification to the honey bees. In this context, LoucifAyad et al. (2010) studying the effects of four acaricides on the metabolism of the worker bees proved that application of Bayvarol ${ }^{\circledR}$ and Apivar® led to a significant reduction in the amounts of protein, carbohydrate, and lipid of the hemolymph, and to a lower extent in the protein and lipid amounts in the body tissues. In contrast, Apiguard $\AA$ and Apilife VAR ${ }^{\circledR}$ had no considerable negative effects on the main biochemical compounds of the hemolymph and the whole body extract of the bees. Despite the considerable toxicity of the $\mathrm{PbF}$ against phoretic varroa mites, adult bees could successfully tolerate its toxic vapors. Since stress tolerance and 
detoxification of xenobiotics are among the most energy-demanding physiological activities in insects (Cresswell et al. 1992; Guedes et al. 2006), depletion of carbohydrate, glycogen, lipid, and protein amounts could be attributed to the involvement and utilization of these macromolecules in detoxifying the toxic ingredients of the $\mathrm{PbF}$.

\section{CONCLUSION}

Low costs (less than US $\$ 1.00$ per colony for a 4-week treatment period), easy to use, and safety for the honey bees are the main advantages of our test $\mathrm{PbF}$. Despite the fact that the efficacy of the $\mathrm{PbF}$ is not comparable with that of the conventional anti-varroa drugs on the market, the results of the present research are a promising step forward for the future studies on this product.

Depending on whether funding is available, we intend to conduct more experiments in order to take a closer look at this new formulation and modify its efficacy and safety.

\section{ACKNOWLEDGMENTS}

The present research was funded by the University of Zabol, Iran. The authors would like to thank Dr. Mahboobeh Sharifi for her assistance on the biochemical tests and Dr. Rasoul Mohammadi Najafabadi for his help with the statistical analyses. Special thanks is due to Daya Nanotechnologists Company for manufacturing the test formulation and providing the analysis of the constructed essential oils. We would also like to acknowledge Ahmad Bahadoran, Ahmad Shekari, Arman Farahbakhsh, Vahid Akbarzadeh, and the rest of the beekeepers involved in the field experiments and appreciate their cooperation.

\section{AUTHORS' CONTRIBUTION}

The authors contributed equally to this work.

\section{COMPLIANCE WITH ETHICAL STANDARDS}

Conflict of interest The authors declare that they have no conflicts of interest.
Évaluation d'une nouvelle formulation à base de plantes pour le traitement de la varroose dans les colonies d'abeilles : efficacité et sécurité.

Varroa destructor / formulation à base de plantes / efficacité acaricide / marge de sécurité / analyses biochimiques.

Beurteilung einer neuen auf Pflanzen basierten Formulierung zur Bekämpfung der Varroose in Honigbienenvölkern: Wirksamkeit und Sicherheit.

Varroa destructor / Pflanzen basierte Formulierung / akatizider Effekt / Sicherheitsbereich / biochemische Analysen.

\section{REFERENCES}

Abbott, W.S. (1925) A method of computing the effectiveness of an insecticide. J. Econ. Entomol. 18, 265-267

Adams, R.P. (1995) Identification of essential oil components by gas chromatography/mass spectroscopy. Allured Publishing Corporation, Carol Stream. pp. 469

Amdam, G.V., Hartfelder, K., Norberg, K., Hagen, A., Omholt, S.W. (2004) Altered physiology in worker honey bees (Hymenoptera: Apidae) infested with the mite Varroa destructor (Acari: Varroidae): a factor in colony loss during overwintering? J. Econ. Entomol. 97 (3), 741-747

Amrine, J.W., Noel, R.C. (2006) Formic acid fumigator for controlling varroa mites. Int. J. Acarol. 32 (2), 115-124

Amrine, J.W., Noel, R.C., Webb, D. (2007) Results of 50\% formic acid fumigation of honey bee hives [Apis mellifera ligustica (Hymenoptera: Apidae)] to control varroa mites (Acari: Varroidae) in brood combs in Florida, U.S.A. Int. J. Acarol. 33 (2), 99-109

Anderson, D.L., Trueman, J.W.H. (2000) Varroa jacobsoni (Acari: Varroidae) is more than one species. Exp. Appl. Acarol. 24, 165-189

Ariana, A., Ebadi, R., Tahmasebi, G.H. (2002) Laboratory evaluation of some plant essences to control Varroa destructor (Acari: Varroidae). Exp. Appl. Acarol. 27, 319-327

Badawy, M.E.I., Nasr, H.M., Rabea, E.I. (2015) Toxicity and biochemical changes in the honey bee Apis mellifera exposed to four insecticides under laboratory conditions. Apidologie 46, 177-193

Badawy, M.E.I., Taktak, N.E.M., Awad, O.M., Elfiki, S.A., Abou El-Ela, N.E. (2016) Preparation of ecofriendly formulations containing biologically active monoterpenes with their fumigant and residual toxicities against adults of Culex pipiens. J. Trop. Med. 3 , $1-8$ 
Bahreini, R., Tahmasebi, G.H., Nowzari, J., Talebi, M. (2004) A study of the efficacy of formic acid in controlling Varroa destructor and its correlation with temperature in Iran. J. Apic. Res. 43 (4), 158-161

Bollhalder, F. (1998) Thymovar for Varroa control. Schweiz Bienen-Zeitung 121 (3), 148-151

Bradford, M. (1976) A rapid and sensitive method for quantitation of microgram quantities of protein utilizing the principle of protein-dye binding. Anal. Biochem. 72 (72), 248-254

Calderone, N.W., Spivak, M. (1995) Plant extracts for control of the parasitic mite Varroa jacobsoni (Acari: Varroidae) in colonies of the western honey bee (Hymenoptera: Apidae). J. Econ. Entomol. 88, 1211-1215

Charpentier, G., Vidau, C., Ferdy, J.B., Tabarta, J., Vetillard, A. (2014) Lethal and sub-lethal effects of thymol on honeybee (Apis mellifera) larvae reared in vitro. Pest Manag. Sci. 70 (1), 140-147

Coffey, M.F., Breen, J. (2013) Efficacy of Apilife Var® and Thymovar® against Varroa destructor as an autumn treatment in a cool climate. J. Apic. Res. 52 (5), 210-218

Cresswell, J.E., Merritt, S.Z., Martin, M.M. (1992) The effect of dietary nicotine on the allocation of assimilated food to energy metabolism and growth in fourthinstar larvae of the southern armyworm, Spodoptera eridania (Lepidoptera: Noctuidae). Oecologia 89 (3), 449-453

Damiani, N., Gende, L.B., Bailac, P., Marcangeli, J.A., Eguaras, M.J. (2009) Acaricidal and insecticidal activity of essential oils on Varroa destructor (Acari: Varroidae) and Apis mellifera (Hymenoptera: Apidae). Parasitol. Res. 106, 145-152

De Jong, D., De Andrea Roma, D., Goncalves, L.S. (1982) A comparative analysis of shaking solutions for the detection of Varroa jacobsoni on adult honey bees. Apidologie 13 (3), 297-306

DeGrandi-Hoffman, G., Ahumada, F., Probasco, G., Schantz, L. (2012) The effect of beta acids from hops (Humulus lupulus ) on mortality of Varroa destructor (Acari: Varroidae). Exp. Appl. Acarol. 58, 407-421

Delaplane, K.S., Van der Steen, J., Guzmán-Novoa, E. (2013) Standard methods for estimating strength parameters of Apis mellifera colonies. J. Apic. Res. 52, $1-12$

Dhifi, W., Bellili, S., Jazi, S., Bahloul, N., Mnif, W. (2016) Essential oils' chemical characterization and investigation of some biological activities: a critical review. Medicines 3 (4), 25

Dietemann, V., Nazzi, F., Martin, S.J., Anderson, D.L., Locke, B., Delaplane, K.S., Wauquiez, Q., Tannahill, C., Frey, E., Ziegelmann, B., Rosenkranz, P., Ellis, J.D. (2013) Standard methods for varroa research. In: Dietemann, V., Ellis, J.D., Neumann, P. (Eds) The COLOSS BEEBOOK, volume II: standard methods for Apis mellifera pest and pathogen research. J. Apic. Res. 52 (1), 1-54

Ellman, G.L., Courthey, K.D., Andres, V., Featherstone, R.M. (1961) A new and rapid colorimetric determination of acetylcholinesterase activity. Biochem. Pharmacol. 7, 88-95

Floris, I., Satta, A., Cabras, P., Garau, V.L., Angioni, A. (2004) Comparison between two thymol formulations in the control of Varroa destructor: effectiveness, persistence, and residues. J. Econ. Entomol. 97, 187191

Gashout, H.A. (2008) Evaluation of natural compounds and different delivery system for controlling the ecotoparasitic mite Varroa destructor (Anderson \& Trueman) in honey bee (Apis mellifera L.) colonies. M.Sc. Thesis, University of Guelph, 94 pp

Gashout, H.A., Guzmán-Novoa, E. (2009) Acute toxicity of essential oils and other natural compounds to the parasitic mite, Varroa destructor, and to larval and adult worker honey bees (Apis mellifera L.). J. Apic. Res. 48 (4), 263-269

Ghasemi, V., Moharramipour, S., Tahmasbi, G.H. (2011) Biological activity of some plant essential oils against Varroa destructor (Acari: Varroidae), an ectoparasitic mite of Apis mellifera (Hymenoptera: Apidae). Exp. Appl. Acarol. 55, 147-154

Ghasemi, V., Moharramipour, S., Tahmasbi, G.H. (2016) Laboratory cage studies on the efficacy of some medicinal plant essential oils for controlling varroosis in Apis mellifera (Hym.: Apidae). Syst. Appl. Acarol. 21, 1681-1692

Giacomelli, A., Pietropaoli, M., Carvelli, A., Iacoponi, F., Formato, G. (2016) Combination of thymol treatment (Apiguard®) and caging the queen technique to fight Varroa destructor. Apidologie 47, 606-616

Giusti, M., Sabelli, C., Di Donato, A., Lamberti, D., Paturzo, C.E., Polignano, V., Lazzari, R., Felicioli, A. (2017) Efficacy and safety of Varterminator, a new formic acid medicine against the varroa mite. J. Apic. Res. 56 (2), 162-167

González-Gómez, R., Otero-Colina, G., VillanuevaJiménez, J.A., Santillán-Galicia, M.T., Peña-Valdivia, C.B., Santizo-Rincón, J.A. (2016) Effects of neem (Azadirachta indica) on honey bee workers and queens, while applied to control Varroa destructor. J. Apic. Res. 55 (5), 413-421

Gracia, M.J., Moreno, C., Ferrer, M., Sanz, A., PeribaÂñez, M.A.Â., Estrada, R. (2017) Field efficacy of acaricides against Varroa destructor. PLoS One 12 (2), e0171633

Grant, D.F., Matsumura, F. (1989) Glutathione $S$-transferase 1 and 2 in susceptible and resistant insecticide resistant Aedes aegypti. Pestic. Biochem. Physiol. 33, 132-143

Gregorc, A., Planinc, I. (2005) The control of Varroa destructor in honey bee colonies using the thymol based acaricide Apiguard®. Am. Bee J. 145 (8), $672-675$

Gregorc, A., Alburaki, M., Werle, C., Knight, P.R., Adamczyk, J. (2017) Brood removal or queen caging combined with oxalic acid treatment to control varroa mites (Varroa destructor) in honey bee colonies (Apis mellifera ). Apidologie 48, 821-832 
Guedes, R.N.C., Oliveira, E.E., Guedes, N.M.P., Ribeiro, B., Serrao, J.E. (2006) Cost and mitigation of insecticide resistance in the maize weevil, Sitophilus zeamais. Physiol. Entomol. 31, 30-38

Habig, W.H., Pabst, M.J., Jakoby, W.B. (1974) Glutathione $S$-transferase, the first step in mercapturic acid formation. J. Biol. Chem. 249, 7130-7139

Imdorf, A., Bogdanov, S. (1999) Use of essential oils for the control of Varroa jacobsoni. Coordination in Europe of research on integrated control of Varroa mites in honey bee colonies. Agricultural Research Centre, Ghent, Belgium, Commission of the European Communities, pp. 17-23

Imdorf, A., Bogdanov, S., Kilchenmann, V., Maquelin, C. (1995) Apilife VAR: a new varroacide with thymol as the main ingredient. Bee World 76, 77-83

Imdorf, A., Bogdanov, S., Ochoa, R.I., Calderone, N.W. (1999a) Use of essential oils for the control of Varroa jacobsoni Oud. in honey bee colonies. Apidologie 30, 209-228

Imdorf, A., Charriere, J.D., Rosenkranz, P. (1999b) Varroa control with formic acid. Coordination in Europe of research on integrated control of Varroa mites in honey bee colonies. Agricultural Research Centre, Ghent, Belgium, Commission of the European Communities, pp. 24-31

Imdorf, A., Bogdanov, S., Kilchenmann, V., Berger, T. (2006) Toxic effects of essential oils and some of their components on Varroa destructor Oud and Apis mellifera L. under laboratory conditions. ALP Sci. 495, 1-18

Islam, N., Amjad, M., Ehsan-ul-Haq., Stephen, E., Naz, N. (2016) Management of Varroa destructor by essential oils and formic acid in Apis mellifera Linn. colonies. J. Entomol. Zool. Stud. 4, 97-104

Kostyukovsky, M., Rafaeli, A., Gileadi, C., Demchenko, N., Shaaya, E. (2002) Activation of octopaminergic receptors by essential oil constituents isolated from aromatic plants: possible mode of action against insect pests. Pest Manag. Sci. 587, 1101-1116

Li, J., Perdue, E.M. (1998) Physicochemical properties of selected monoterpenes. Environ. Int. 24 (3), 353-358

Li, X., Schuler, M.A., Berenbaum, M.R. (2007) Molecular mechanisms of metabolic resistance to synthetic and natural xenobiotics. Annu. Rev. Entomol. 52, 231-253

Loucif-Ayad, W., Aribi, N., Soltani, N. (2008) Evaluation of secondary effects of some acaricides on Apis mellifera intermissa (Hymenoptera, Apidae): acetylcholinesterase and glutathione S-transferase activities. Eur. J. Sci. Res. 21 (40), 642-649

Loucif-Ayad, W., Aribi, N., Smagghe, G., Soltani, N. (2010) A scientific note on the impact of acaracides on the nutritional biochemistry of Apis mellifera intermissa (Hymenoptera: Apidae). Apidologie 41, $135-137$

Maggi, M., Gende, L., Russo, K., Fritz, R., Eguaras, M. (2011) Bioactivity of Rosmarinus officinalis essential oils against Apis mellifera, Varroa destructor and
Paenibacillus larvae related to the drying treatment of the plant material. Nat. Prod. Res. 25 (4), 397-406

Mahdavi Moghadam, M., Ghadamyari, M., Talebi, K.H. (2012) Resistance mechanisms to fenazaquin in Iranian populations of two-spotted spider mite, Tetranychus urticae Koch (Acari: Tetranychidae). Int. J. Acarol. 38, 138-145

Rademacher, E., Harz, M., Schneider, S. (2015) The development of HopGuard $\AA$ as a winter treatment against Varroa destructor in colonies of Apis mellifera. Apidologie 46, 748-759

Rajendran, S., Sriranjini, V. (2008) Plant products as fumigants for stored-product insect control. J. Stored Prod. Res. 44, 126-135

Ramzia, H., Ismailib, M.R., Aberchaneb, M., Zaanouna, S. (2017) Chemical characterization and acaricidal activity of Thymus satureioides C. \& B. and Origanum elongatum E. \& M. (Lamiaceae) essential oils against Varroa destructor Anderson \& Trueman (Acari: Varroidae). Ind. Crop. Prod. 108, 201-207

Rosenkranz, P., Aumeier, P., Ziegelmann, B. (2010) Biology and control of Varroa destructor. J. Invertebr. Pathol. 103, 96-119

Ruffinengo, S., Eguaras, M., Floris, I., Faverin, C., Bailac, P., Ponzi, M. (2005) LD $_{50}$ and repellent effects of essential oils from Argentinian wild plant species on Varroa destructor. J. Econ. Entomol. 98, 651-655

Sabahi, Q., Gashout, H., Kelly, P.G., Guzman-Nonoa, E. (2017) Continuous release of oregano oil effectively and safely controls Varroa destructor infestations in honey bee colonies in a northern climate. Exp. Appl. Acarol. 72, 263-275

Schenk, P., Imdorf, A., Fluri, P. (2001) Effects of neem oil on Varroa mites and bees. Am. Bee J. 141, 878-879

Shaaya, E., Rafaeli, A. (2007) Essential oils as biorational insecticides - potency and mode of action. In: Ishaaya, I., Nauen, R., Rami Horowitz, A. (Eds), Insecticides design using advanced technologies. Springer-Verlag, Berlin, pp. 240-261

Stanimirović, Z., Glavinić, U., Lakić, N., Radović, D., Ristanić, M., Tarić, E., Stevanović, J. (2017) Efficacy of plant-derived formulation "Argus Ras" in Varroa destructor control. Acta Vet-Beograd 67 (2), 191-200

Tananaki, C., Goras, G., Huggett, N., Karazafiris, E., Dimou, M., Thrasyvoulou, A. (2014) Evaluation of the impact of Exomite Pro ${ }^{\mathrm{TM}}$ on Varroa mite (Varroa destructor) populations and honeybee (Apis mellifera) colonies: efficacy, side effects and residues. Parasitol. Res. 113 (4), 1251-1259

Tihelka, E. (2018) Effects of synthetic and organic acaricides on honey bee health: a review. Slov. Vet. Res. 55 (2), 119-40

Van Asperen, E. (1962) A study of housefly esterase by mean of a sensitive colorimetric method. J. Insect Physiol. 8, 401-416

Van der Horst, D.J., Vroemen, S.F., Van Marrewijk, W.J.A. (1997) Metabolism of stored reserves in insect fat body: hormonal signal transduction implicated in glycogen mobilization and biosynthesis of the 
lipophorin system. Comp. Biochem. Physiol. 117B (4), 463-474

Weick, J., Thorn, R.S. (2002) Effects of acute sublethal exposure to coumaphos or diazinon on acquisition and discrimination of odor stimuli in the honey bee (Hymenoptera: Apidae). J. Econ. Entomol. 95 (2), 227-236

Yuval, B., Kaspi, R., Shloush, S., Warburg, M.S. (1998) Nutritional reserves regulate male participation in Mediterranean fruit fly leks. Ecol. Entomol. 23 (2), 211-215

Zemene, M., Bogale, B., Derso, S., Belete, S., Melaku, S., Hailu, H. (2015) A review on varroa mites of honey bees. Acad. J. Entomol. 8 (3), 150-159
Zhu, Y.C., Yao, J., Adamczyk, J., Luttrell, R. (2017) Synergistic toxicity and physiological impact of imidacloprid alone and binary mixtures with seven representative pesticides on honey bee (Apis mellifera ). PLoS One 12 (5), e0176837

Publisher's note Springer Nature remains neutral with regard to jurisdictional claims in published maps and institutional affiliations. 